Vol.8, Issue 1, pp.32-44, January 2020

Published by ECRTD- UK

Print ISSN: ISSN 2054-6351 (print), Online ISSN: ISSN 2054-636X (online)

\title{
USE OF EFFECTIVE BRAINSTORMING TECHNIQUE ON STANDARD SEVEN \\ LEARNERS' ACHIEVEMENT IN ENGLISH COMPOSITION WRITING IN PUBLIC PRIMARY SCHOOLS IN KISUMU COUNTY, KENYA
}

\author{
${ }^{1}$ Kamau Wambui Hellen $\quad{ }^{2}$ Odundo Amollo Paul $\quad{ }^{3}$ Inyega Nasimiyu Hellen \\ Department of Educational Communication \& Technology \\ University of Nairobi \\ Kikuyu Camps \\ P.O BOX 177 Kisumu, Kenya.
}

\begin{abstract}
Adaptation of brain storming technique to teach standard seven learners in English composition writing offers the learners an opportunity to work well together with behaviour, collaboration and communication well natured .The objective was to determine the influence of whole class technique on learners' achievement in composition writing skills in public primary schools in Kisumu County. The piagets theory 1967 was used to determine brain storming, technique on standard seven learners achievement in English composition writing skills. Non-equivalent control group with pre and post-test groups research design was adopted. The sample size of 292 was drawn from 6 teachers of English, 6 head teachers and standard seven pupils in public schools. Data was collected via questionnaire, observation schedules and check lists. Analysis was done using descriptive statistics.The findings indicated that brain writing strategy is moderately used ( $m=3.40 S D$ of 1.269), pie storm teaching technique is highly used $(m=3.733$ and $S D$ of 1.796), and brain wave and brain writing strategy relatively contribute to learners' composition writing skills The computed $z$ values for brainstorming technique elements revealed a z-statistic value higher than the z-Critical value and P-value less than 0.05. Thus, the study rejected the entire five Null hypotheses as there was a statistically significant relationship between: individual group technique, whole class technique, small group technique, round robin technique and relay technique; and learners' achievement in composition writing skills in public primary schools in Kisumu County. For policy makers and implementers, ministry of Education and Kenya National Examination Council, should address the use of inquiring-based learning in order to provoke critical-thinking in learners as the new (CBC) gets rooted to curb the negative attitude of embracing change of teaching for life and not for exams. For theory similar studies should be carried out using inferential statistics, especially multiple regression analysis to assess how the individual strategies of brainstorming teaching technique contribute to overall learners' learning achievements. Other researches can use the Humanist child development theory to cater for the concerns of a paradigm shift to the thinking about holistic development of the learners. .
\end{abstract}

KEY WORDS: Learners' achievements, composition writing, individual group strategy, whole group strategy, small group strategy, round robin group strategy, writing, relay group strategy. 
Vol.8, Issue 1, pp.32-44, January 2020

Published by ECRTD- UK

Print ISSN: ISSN 2054-6351 (print), Online ISSN: ISSN 2054-636X (online)

\section{INTRODUCTION}

\section{Individual Group Technique and Learners' Composition Writing Skills}

Individual group technique is a dimension of brainstorming method with various subdimensions such as free writing, mind-mapping, word-play and role-play. In individualgroup technique, ideas are generated and each is considered to comply with a complete document. The components are all special in that they all contribute to the whole of the group work. According to Crowe and Sheppard (2015), mind maps reveal that although decisions made in one area of research methods may affect decisions made in another, there is no predetermined connection between each area and the research design chosen. The findings of the study showed that mind maps can be used to guide in teaching through the concepts of research methods and may help to produce more robust research. The findings of the study revealed that reviewing of mind mapping has its constituents and the uses, reviewing the computer based mind mapping software, literature on skit tools and how good they are at interface design and their widget based computers. The research discovered that there are many challenges in sketch tools and the three impediments were shown as link recognition, structure analysis and link reflow.

Hun and Chik (2018) investigated the effectiveness of mind mapping in relation to learners' academic performance in class and for which class- 8 social science subject case study for mind mapping was designed. The findings were that that mind mapping was more effective than traditional teaching The study also found that mind mapping focused on assessing the feasibility and the applicability of the mind map technique and effective tools for summarizing understanding and recalling information. The findings were that mind mapping is effective because $100 \%$ of information recalled increased and participants' achievement marks improved.

Mwangi (2016) conducted a study in public secondary schools in Meru County, Kenya. This study established that teaching strategies such as role play, simulation, language games and mime have a significant influence on learner achievement. Mwangi emphasized that dramatization is an effective strategy in teaching the English language and promoting learner achievement in Igembe North and ImentiSouth District, in Kenya. Crowe and Shappard (2015) who supports use of mind maps and Chausiya (2012) who supports role play, all agree that individual technique in brainstorming is effective in developing speaking, confidence and improving inter-personal skills.

\section{Whole Group Technique and Learners' Composition Writing Skills}

Whole group strategy gives learners enough opportunities to articulate their ideas liberally about the main topic given by the educator. Barr (2016), in a vivid study of reading skills for secondary school education in Minnesota Public schools summed up that, majority of the students in Minnesota struggle in the area of reading comprehension. Almutairi (2015) puts it further that there are statistical significant differences at the levels of (a-0.05) between the experimental group and the control group in the total score and the sub score of the creative thinking in the favour of the experimental group indicating the effectiveness of using brainstorming strategy in developing creative thinking skills. The researcher recommended the use of this strategy in Kuwait schools. Alshammari (2015) indicated that the results of 
Vol.8, Issue 1, pp.32-44, January 2020

Published by ECRTD- UK

Print ISSN: ISSN 2054-6351 (print), Online ISSN: ISSN 2054-636X (online)

the study showed statistically significant differences in the achievement and the total of achievement in favour of the experimental group that he studied using the brainstorming as an instructional strategy in education and that the elementary teachers should use Brainstorming in their daily lesson plans

Kentucky (2015) noted a statistically significant correlation between intercultural sensitivity and foreigner languages teaching motivation using brainstorming method According to Osborn (1953), this method encourages participants to provide wild and unexpected answers. Ore set et al (2014) states that, in order to achieve the desired outcome of brain writing technique, clearly formulated ideas should be avoided so that participants can be more creative. Because it runs quietly, some participants can concentrate better, which leads to a greater flow of ideas.

\section{Small Group Technique and Learners' Composition Writing Skills}

Small group teaching approach is usually very teacher-centred. It has a sub -dimension of brainstorming with four sub-dimension namely three minutes group, buzz group strategy and revised group strategy. According to Hanna, Taqai and Nowieyah (2014), the instructor took notes of her observation of the formation of and participation in group work. It was found that the students who worked in groups did not improve. However, most students reported that they enjoyed the tasks and would like to work in a group more often. The method of forming a group also seemed to affect learning. It was found that social and academic variables of age and GPA affected the formation, engagement and results of group work.

David et al (2013) in the skill of writing on small group teaching puts more strength on the truth that it is more satisfying to facilitators and learners. Thus this methodology is recognized as the best to be embraced by higher education and worth instilling and nurturing. In addition, emphasis on how teachers need to use motivation to learners these is effective as learners' participants in the group work. They further reveals that teachers especially in shaping behaviour of learners are vital in the classroom scenery. A study that investigated the influence of buzz group technique in composition writing was conducted by Mash (2015). The study explored the functioning of buzz group strategy (BGS) in bettering learners' energy and writing skill of hortatory exposition text at the eleventh-grade students of MAACKHORIYYAH Semarang in academic year of 2014l2015 and to know the enhancements of students and writing skill of hortatory exposition text after being taught using Buzz Group Technique Buzz group technique can enhance student activeness and writing skills of hortatory exposition text. The result of the study showed that students enhance their activeness and writing skills by using buzz group technique. Pangaribun, T \&Manik, S (2018), affirms that Buzz group is significantly effective writing skill of learners. In addition, Buzz groups values all views from all participants. 
Vol.8, Issue 1, pp.32-44, January 2020

Published by ECRTD- UK

Print ISSN: ISSN 2054-6351 (print), Online ISSN: ISSN 2054-636X (online)

\section{Round-Robin Technique and Learners' Achievement in Composition Writing Skills}

Round Robin group is a sub -dimension of brainstorming with four sub-dimension namely, individual group, whole group, small group strategy, and relay group strategy. According to Ikwemelu and Oyibe (2014), learners are inquisitive in inquiring which facilitates ways of resolving challenges. Upandhya (2012) in his study reveals past trends that channels and ways of teaching English has taken off in the new ways of delivery. Oyibe (2014) puts emphasis that learners are imaginative and inventive in problem solving and thus genesis of problems are recognized and solutions offered. Past trends and future instructions establish out that ways and means of teaching English is changed conditions of todayAstuti and Kumalarini (2013) established that whole group brainstorming can progress the writing ability of grade ten students of SMAN 12 Surabaya in writing descriptive texts. It can improve all the apparatus of the students' composition except "mechanics". Noor, (2013) asserts that brainstorming method offers a good process to make the students exercise in writing.

Relay Technique on Learners' Achievement in Composition WritingRelay group is a sub -dimension of brainstorming with two sub-dimension namely, Skills Group and Resources Group. Relay group allows learners to build on their self-esteem, control their lives and be able to make decisions and judge their action confidently. This happens when presentations are being done, critiquing their group work and when passing the papers from one individual to the other. A lot of personality building is natured, encouraged and that translate to high esteem level acquired. Xin (2014) revealed that the transmission, reliability and maintaining of how processing delays. They proposed a novel to equalize-and-forward (EF) relay, scheme which equalizes channels between sources/relay and for English eliminates the channel accumulation effects. His study is currently relevant to my study as the resources have been used in mathematical tractability. However, it still lacked basis in that the resource strategies he examined only emphasized on mathematics while this study investigated its applications in composition writing.

KCPE Mean Scores in English Language and Composition for Kisumu County Between 2014 to 2017

\begin{tabular}{|l|l|l|l|l|l|}
\hline \multirow{2}{*}{ Category } & \multicolumn{5}{|c|}{ Mean Score Performance } \\
\cline { 2 - 6 } & 2013 & 2014 & 2015 & 2016 & $\begin{array}{l}201 \\
7\end{array}$ \\
\hline Language & $\begin{array}{l}53.0 \\
6\end{array}$ & $\begin{array}{l}47.6 \\
2\end{array}$ & $\begin{array}{l}49.9 \\
8\end{array}$ & $\begin{array}{l}50.5 \\
2\end{array}$ & $\begin{array}{l}47.6 \\
2\end{array}$ \\
\hline $\begin{array}{l}\text { Compositi } \\
\text { on }\end{array}$ & $\begin{array}{l}41.9 \\
0\end{array}$ & 41.4 & 51.3 & 40.2 & 39.6 \\
\hline
\end{tabular}

Source: The Kenya National Examination Council (2017). 
Vol.8, Issue 1, pp.32-44, January 2020

Published by ECRTD- UK

Print ISSN: ISSN 2054-6351 (print), Online ISSN: ISSN 2054-636X (online)

\section{Statement of the Problem}

In Kenya the national Examination Council has shown Primary schools learners have over the years performed poorly as indicated in the (KNEC Examination Report 2013-2017 demonstrated on the table above. Therefore, the delivery of the curriculum, monitoring and examination needs to be looked into to understand exactly where the gap is. This study has observed that the approaches taken by the teachers to deliver in Kisumu County have generally contributed to the overall results in National examinations (field observation). This study suggests that teachers of English while handling composition writing have to embrace different methods to use when teaching writing skills.

The Kenyan primary syllabus has emphasized on the resources, pedagogy of handling each component that translate to the overall performance of English language. The table shown above has shown that the grammar is better performed then the composition writing skills. Both have to be handled well since they both add up to the final grade for English as a whole paper. This is wanting since all instruction and assessment is done through the language despite its poor performance expect Kiswahili which performance well in insha writing than sarufi as evidence stipulated in (the KNEC) Examination Report 2013 -2017.

The new curriculum (CBC) has a lot of emphasis on Literacy activities especially to address the four skills which are very vital in the overall performance of English language. The brain storming technique has not been elaborated and comprehensively be looked at as a teaching strategy that can enhance critical thinking, idea generation to boost the writing skills by the stalk holders ,the Ministry of Higher Education and Science and technology, The Kenya institute of curriculum development. Therefore, this study provides information on the influence of brain storming technique on standard seven learner's achievement in English composition writing in public primary schools in Kisumu County, Kenya. This study has demonstrated the need and urgency of its adoption and implementation.

\section{Purpose and Objective}

The study purposed to determine teachers' influence of brainstorming techniques in composition writing skills of English language in the influence of brave wave, brain storming, pie storm and brain writing of whole class technique on learners' achievement in composition writing skills in public primary schools in Kisumu County.

\section{CONCEPTUAL FRAME WORK}

According to Orodho (2009) a conceptual framework is a model of representation where a researcher conceptualizes or represents the relationships between variables in the study and shows the relationship graphically or diagrammatically. The independent variables are brainstorming techniques in composition writing which are: individual technique, whole group technique, small group technique, round robin technique and relay technique. The dependent variable is the pupils' achievement and it's indicated by improved classroom participation, personalized learning and, active learning, improved thinking skills, improved writing skills, good usage of vocabulary and good sentence construction. This interplay between the independent and dependent variables is extraneously influenced by various factors such as: background knowledge, linguistic knowledge, and training of the teachers. The inter relationship among variables are conceptualized as illustrated in Figure 2.1. Brain 
Vol.8, Issue 1, pp.32-44, January 2020

Published by ECRTD- UK

Print ISSN: ISSN 2054-6351 (print), Online ISSN: ISSN 2054-636X (online)

storming technique is perceived to be a strong technique in influencing and strengthening learner's achievement

Independent Variables

Dependent Variables

Brain storming technique

$>$ Individual group

$>$ Whole group

$>$ Small group

$>$ Roun Robin ggrou

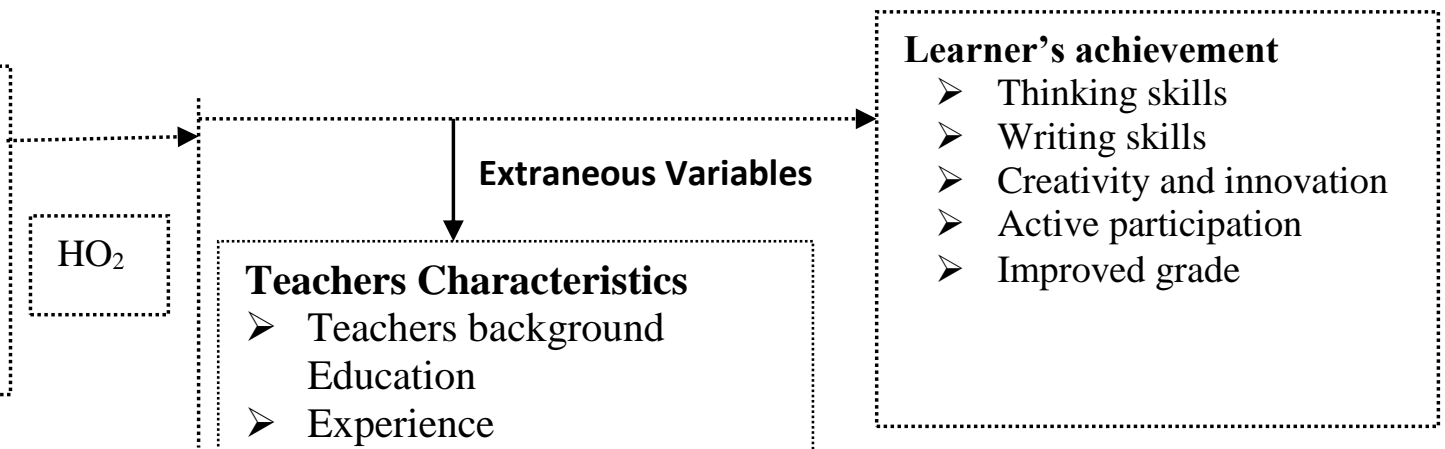

$>$ Teaching methodology

Learners Characteristics

$>$ Learners background

$>$ Learners entry behavior and attitude

\section{STUDY FINDINGS AND DISCUSSIONS}

Determine the Influence of Whole Class Technique on Learners' Achievement in Composition Writing Skills in Public Primary Schools in Kisumu County

The objective sought to examine the influence of whole group technique on learners' achievement in composition writing skills. The questions for this analysis were extracted from teachers of English questionnaire part F (questions 1-9) and learners questionnaire part $\mathrm{F}$ (questions 1-9). The hypothesis tested under this objective was, $\mathrm{HO}_{2}$ (There is no statistically significant differences between whole class technique and learners' achievement in composition writing skills in public primary schools in Kisumu County). The objective was analysed on two stages using likert scale questions. Results are presented and discussed below.

\section{Hypothesis Testing for Whole Group Technique}

This study sought to test the second Null Hypothesis $\left(\mathrm{HO}_{2}\right)$ which assumed no statistical significant relationship between whole group technique and learners' achievement in composition writing skills in public primary schools in Kisumu County. The result for Z-test statistics are shown in Table 5.2 
Vol.8, Issue 1, pp.32-44, January 2020

Published by ECRTD- UK

Print ISSN: ISSN 2054-6351 (print), Online ISSN: ISSN 2054-636X (online)

\begin{tabular}{llll}
\hline & & \multicolumn{2}{l}{ Experiment Group } \\
\cline { 3 - 4 } Technique & & z-Statistics & P-value \\
\hline $\begin{array}{l}\text { Whole } \\
\text { technique }\end{array}$ & group & 8.23982 & 0.0012 \\
\hline
\end{tabular}

Results from Table 4.28 revealed that the whole group technique computed $z$ statistic showed $z=8.23982$ and $p=0.0012$. The $p$-value was less than the $0.05(p<0.05)$ which is the bench mark value for rejecting the Null Hypothesis assuming 95\% significance level. Therefore, the study rejected that Null Hypothesis, as there was a statistically significant relationship between whole group technique and learners' achievement in composition writing skills in public primary schools in Kisumu County Whole group Technique Influence on Learners Achievement

The second phase of analysis sought to determine how whole group teaching technique of brainstorming influences learners' achievement. Learner respondents were asked to rate on a five Likert point scale - (with 1=Strongly Disagree, 2=Disagree, 3=Indifferent, 4=Agree and $5=$ Strongly Agree) - the extent to which they agreed with the posed questions on indicators of whole group strategies. Results are discussed below.

\section{Hypothesis Testing for Whole Group Technique}

This study sought to test the second Null Hypothesis $\left(\mathrm{HO}_{2}\right)$ which assumed no statistical significant relationship between whole group technique and learners' achievement in composition writing skills in public primary schools in Kisumu County. The result for Z-test statistics are shown in Table 5.3

Table 5.3: z-Test for Whole Group Techniques

\begin{tabular}{lll}
\hline & Experiment Group & \\
\cline { 2 - 3 } Technique & z-Statistics & P-value \\
\hline Whole group technique & 8.23982 & 0.0012 \\
\hline
\end{tabular}

Results from Table 4.28 revealed that the whole group technique computed $\mathrm{z}$ statistic showed $\mathrm{z}=8.23982$ and $\mathrm{p}=0.0012$. The $\mathrm{p}$-value was less than the $0.05(\mathrm{p}<0.05)$ which is the bench mark value for rejecting the Null Hypothesis assuming 95\% significance level. Therefore, the study rejected the Null Hypothesis, as there was a statistically significant relationship between whole group technique and learners' achievement in composition writing skills in public primary schools in Kisumu County.

Objective Three: Examine the Influence of Small Groups' Technique on Learners' Achievement in Composition Writing Skills in Public Primary Schools in Kisumu County

The third objective sought to examine the influence of small group technique on learners' achievement in composition writing skills. The questionnaire for teachers of English Part G (Questions 1-12) and learners' questionnaire Part G (Questions 1-12) provided responses for this objective. The hypothesis tested under this objective was, $\mathrm{HO}_{3}$ : There is no statistically significant difference between small group technique and learners' achievement in 
composition writing in public primary schools in Kisumu County. The objective was analyzed in three stages using various Likert scale ratings.

\section{Hypothesis Testing for Small Group Technique}

This study sought to test the third Null Hypothesis $\left(\mathrm{HO}_{3}\right)$ which assumed no statistical significant relationship between small group technique and learners' achievement in composition writing skills in public primary schools in Kisumu County. The result for Z-test statistics are shown in Table 5.4

Table 5.4: z-Test for Small Group Techniques

\begin{tabular}{lll}
\hline & Experiment Group & \\
\cline { 2 - 3 } Technique & z-Statistics & P-value \\
\hline Small group technique & 24.09581 & 0.0000 \\
\hline
\end{tabular}

Result from Table 4.35 revealed that the small group technique computed $\mathrm{z}$ statistic showed $\mathrm{z}=24.09581$ and $\mathrm{p}=0.0000$. The $\mathrm{p}$-value was less than the $0.05(\mathrm{p}<0.05)$ which is the bench mark value for rejecting the Null Hypothesis assuming 95\% significance level. Therefore, the study rejected the Null Hypothesis, as there was a statistically significant relationship between small group technique and learners' achievement in composition writing skills in public primary schools in Kisumu County.

Objective Four: Determine the Influence of Round Robin Technique on Learners' achievement in Composition writing skills in Public Primary Schools in Kisumu County.

The study objective four examined the influence of Round Robin technique on learners' achievement in composition writing skills. The questionnaire for teachers of English questionnaire Part H (Questions 1-10) and learner's questionnaire Part H (Questions 1-10 provided response for objective four. The hypothesis tested under objective four was $\mathrm{HO}_{4}$ : There is no statistically significant difference between Round Robin technique and learners' achievement in composition writing skills in public primary schools in Kisumu County. This objective was analyzed in three stages based on various Linkert scales. Results are discussed below.

\section{Hypothesis Testing for Round Robin Technique}

This study sought to test the fourth Null Hypothesis $\left(\mathrm{HO}_{4}\right)$ which assumed no statistical significant relationship between round robin technique and learners' achievement in composition writing skills in public primary schools in Kisumu County. The result for Z-test statistics are shown in Table 5.5

Table 5.5: z-Test for Round Robin Techniques

\begin{tabular}{lll}
\hline & Experiment Group & \\
\cline { 2 - 3 } Technique & z-Statistics & P-value \\
\hline Round Robin technique & 14.067 & 0.0001 \\
\hline
\end{tabular}


Vol.8, Issue 1, pp.32-44, January 2020

Published by ECRTD- UK

Print ISSN: ISSN 2054-6351 (print), Online ISSN: ISSN 2054-636X (online)

Result from Table 4.42 revealed that the computed $\mathrm{z}$ statistic for Round Robin techniques $\mathrm{z}=14.067$ and $\mathrm{p}=0.0001$. The computed $\mathrm{p}$-value was less than the 0.05 , that is $\mathrm{p}<0.05$, which is the bench mark value for rejecting the Null Hypothesis assuming 95\% significance level. Therefore, the study rejected the Null Hypothesis as there was a statistically significant relationship between Round Robin technique and learners' achievement in composition writing skills in public primary schools in Objective Five: Examine Influence of Relay Technique on Learners' achievement in composition writing Skills in Public Primary Schools in Kisumu County

The fifth and last study objective sought to determine the influence of relay group technique on learners' achievement in composition writing skills. The questionnaire for teachers of English (Part I - Questions 1-2) and learners' questionnaire (Part I - Questions 1-2) provided responses for Objective One. The hypothesis tested under this objective was, $\mathrm{HO}_{5}$ : There is no statistically significant relationship between relay group technique and learners' achievement in composition writing skills in public primary schools in Kisumu County. The objective was analyzed in three stages using various Liker scale ratings

\section{Hypothesis Testing for Relay Technique}

This study sought to test the fifth Null Hypothesis $\left(\mathrm{HO}_{5}\right)$ which assumed no statistical significant relationship between relay technique and learners' achievement in composition writing skills in public primary schools in Kisumu County. The result for z-test statistics are shown in Table 5.6.

Table5.6: z-Test for Relay Techniques

\begin{tabular}{lll}
\hline & Experiment Group Technique & \\
\cline { 2 - 3 } Technique & z-Statistics & P-value \\
\hline Relay technique & 14.8568 & 0.0001 \\
\hline
\end{tabular}

Result from Table 4.47 revealed the computed $\mathrm{z}$ statistic for relay techniques $\mathrm{z}=14.8568$ and $p=0.0001$. The computed $p$-value was less than the 0.05 , that is $p<0.05$, which is the bench mark value for rejecting the Null Hypothesis assuming 95\% significance level. Therefore, the study rejected the Null Hypothesis as there was a statistically significant relationship between relay technique and learners' achievement in composition writing skills in public primary schools in Kisumu County.

\section{CONCLUSION}

The study draws the following conclusions based on key findings for every objective. Conclusion for objective one examined the influence of individual group technique on learners' achievement in composition writing skills. The study concludes that individual technique of brainstorming learning is sometimes used in teaching composition writing in public primary schools. The moderate adoption can be linked to poor use of mind mapping strategy and low use of word play strategy. However, free writing strategy and role play 
strategy are embraced. Thus, individual group technique positively influences learners' achievement in composition writing skills in public primary schools.

Conclusion for objective two which assessed the influence of whole group technique on learners' achievement in composition writing skills in public primary schools in Kisumu County. The study concludes that brain writing strategy is moderately used in teaching composition writing in public primary schools and pie storm teaching technique is highly used in teaching composition in public primary schools. In addition, use of brain storming, brain wave, and brain writing strategies relatively contributes to learners' composition writing skills. Thus, whole group technique positively influences learners' achievement in composition writing skills in public primary schools.

Conclusion for objective three which examined the influence of small groups' technique on learners' achievement in composition writing skills in public primary schools in Kisumu County. For small group learning technique, the study concludes that revised strategy and buzz strategy are moderately used in teaching composition in public primary schools. Three minutes strategy and small group are highly used in teaching composition in public primary schools. In addition, small group technique and small group technique positively influence learners' achievement in composition writing skills in public primary schools.

Conclusion for objective four which assesses the influence of round robin technique on learners' achievement in composition writing skills in public primary schools in Kisumu County. The study concludes that individual strategy and small group strategy are poorly adopted in teaching composition writing in public primary schools. On the other hand Whole Group Strategy is highly used. Furthermore, learners' response on their understanding of round robin technique improves their composition writing ability. In addition, round robin technique positively influences learners' achievement in composition writing skills in public primary schools.

Lastly, the study concludes for relay technique that skills strategy is never used in teaching composition writing and resource strategy is seldom used in teaching composition writing in public primary schools in Kisumu County. In addition, the use of resource strategy enables learners to share resources to write a piece as a group and thus do not fear to share their experience with their classmates. Finally yet importantly, the use of brainstorming teaching technique increases pass rate by $33.5 \%$ thus learners' great achievement.

\section{RECOMMENDATIONS}

Based on the key findings and conclusions made by the study, the following recommendations are presented:

* For policy makers and implementers, ministry of Education and Kenya National Examination Council, should address the use of inquiring-based learning in order to provoke critical-thinking in learners as the new (CBC) gets rooted to curb the negative attitude of embracing change of teaching for life and not for exams. 
Vol.8, Issue 1, pp.32-44, January 2020

Published by ECRTD- UK

Print ISSN: ISSN 2054-6351 (print), Online ISSN: ISSN 2054-636X (online)

* For theory similar studies should be carried out using inferential statistics, especially multiple regression analysis to assess how the individual strategies of brainstorming teaching technique contribute to overall learners' learning achievements.

* Other researches can use the Humanist child development theory to cater for the concerns of a paradigm shift to the thinking about holistic development of the learners. .

\section{REFERENCES}

Al-Magharwry, A. "Effectiveness of using the brainstorming technique to learn some basic Skills and collection of knowledge for beginners in volley ball'. World Journal of Sport Sciences, 6(4), 361-366, 2012

Alshammari, M. K. "Effective brainstorming in teaching social studies for elementary schools in Saudi Arabia'. Journal of Education \& Social Policy, 2(3), 70 - 75, September, 2015.

Barr, A. (1991), Descriptive study of reading strategies for secondary school education in Minnesota public schools. New York: Berkeley Books.

Ikwemelu, B., \&Oyibe, Y. (2014). The Comparative Effects of Simulation Games and Brainstorming Instructional Strategies on Junior Secondary School Students' Achievement in Social Studies in Nigeria.

Kothari, C.R (2004), "Research Methodology methods \& Techniques" (2ndedn.). New Delhi: New Age International Publisher.

Kenya National Examination Council, (2007-2013). Kenya Certificate of Secondary Examination. Nairobi: KNEC.

Kothari, C. (2008). Research Methodology (2nd Edition). New Delhi: New Age International.

Kothari, C. (2008). Research Methodology (2nd Edition). New Delhi: New Age International.

Martal, A. (2014). The Role of Computer Assisted Language Learning (CALL) for English Language learning of Elementary and High Schools In Indonesia in Journal Register volume 5, No. 2.

Mugenda, M. O. \&Mugenda G.A (2003).Research method: Quantitative and qualitative approaches. Nairobi: African Centre for Technology Studies.

Mugenda, A.G. (2008). Social Science Research. Nairobi: Acts Press.

Mugenda, O. \& Mugenda, .A. (2003). Research Methods: Quantitative and Qualitative Research Approaches. Nairobi: Act Press.

Mugenda, O. \& Mugenda, .A. (2003). Research Methods: Quantitative and Qualitative Research Approaches. Nairobi: Act Press.

Ni'Mah, (2015).Introduction: What is reading? In C. Alderson, \& A. H. Urquhart (Eds.), Reading in a foreign language (pp. 16-28). London \& New York: Longman. Nunan D. (1991). Research Methods in Language Learning. Cambridge: Cambridge University Press.

Osborn, A.F., (1953). Applied imagination. Scribner's, New York.

Osborn, A.F., (1963). Applied imagination (3rd end). Scribner's, New York.Glazerman, S., Levy, D, \& Myers, D. (2002).No experimental replications of social experiments: A systematic review. Dallas, TX: Mathematical Policy Research. 
Vol.8, Issue 1, pp.32-44, January 2020

Published by ECRTD- UK

Print ISSN: ISSN 2054-6351 (print), Online ISSN: ISSN 2054-636X (online)

Oyibe, J. (2014). Effects of a computer-assisted concept mapping learning strategy on EFLcollege students' English reading comprehension. Computers \& Education, 54, 436-445..

Osborn, A. F. “Applied imagination: Principles and procedures of creative thinking'. New York: Charles Scribner's Sons, 1953.

Osborn, A. F. "Applied imaginations: Principles and procedures of creative problem solving. (3rd Rev. edition)'”. New York: Charles Scribner's Sons, 1963.

Orodho J.A. (2004). Elements of Education and Social Research Methods. Nairobi: Reata.

Piaget, J. (1950). Play, Dreams and Imitation in Children. London: R.P.K.

Piaget, J. \& Inhelder, B. (1969). The Psychology of the Child. London: Routledge \& Kegan Paul.

Piaget, J. 'Piaget's theory”, in Handbook of child Psychology, 3rd ed, vol 1. P. Mussen, Ed. New York: Willey, 1970, pp. 703-732.

Al-Magharwry, A. "Effectiveness of using the brainstorming technique to learn some basic Skills and collection of knowledge for beginners in volley ball". World Journal of Sport Sciences, 6(4), 361-366, 2012

Alshammari, M. K. "Effective brainstorming in teaching social studies for elementary schools in Saudi Arabia', Journal of Education \& Social Policy, 2(3), 70 - 75, September, 2015.

Dantas, W. (2002).Implementing cooperative learning: a field of study evaluating issues for school based consultants.Journal of school psychology, 32, 67-84.

David, M and Alexander, P (2013): Small Group Teaching; a toolkit for teaching. The Higher Academy

Ikwemelu, B., \&Oyibe, Y. (2014).The Comparative Effects of Simulation Games and BrainstormingInstructional Strategies on Junior Secondary School Students' Achievement in Social Studies in Nigeria.

Kamau, W, Odundo,P.\& Inyega, H (2019) Adoption of Whole Group Strategy on Standard Seven Learners' Achievement in English Composition Writing in Public Primary Schools in Kisumu County, Kenya Journal of Education and Practice www.iiste.orgISSN 2222-1735 (Paper) ISSN 2222-288X (Online) DOI: 10.7176/JEPVol.10, No.3, 2019

Kamau ,W. (2019).Adoption of Small Group Technique on Standard Seven Learners' Achievement In English Composition Writing In Public Primary Schools In Kisumu County, Kenya Journal Homepage: -www.journalijar.com Article DOI:10.21474/IJAR01

KamauW, Odundo P, Inyega H,(2019) "Effects of Individual Technique on Standard Seven Learners Achievement in English Composition Writing in Public Primary Schools in Kisumu County, Kenya", International Journal of Science and Research (IJSR), https://www.ijsr.net/archive/v8i4/ART20197112.pdf, Volume 8 Issue 4, April 2019, $1180-1187$

Kenya National Examination Council, (2007-2013). Kenya Certificate of Secondary Examination. Nairobi: KNEC.

Kothari, C. (2008). Research Methodology (2nd Edition). New Delhi: New Age International.

Kothari, C.R (2004), Research Methodology methods \& Techniques (2ndedn.). New Delhi: New Age International Publisher.

Mugenda, A.G. (2008). Social Science Research. Nairobi: Acts Press. 
Vol.8, Issue 1, pp.32-44, January 2020

Published by ECRTD- UK

Print ISSN: ISSN 2054-6351 (print), Online ISSN: ISSN 2054-636X (online)

Mugenda, M. O. \& Mugenda A G. (2003).Research method: Quantitative and qualitative approaches. Nairobi: African Centre for Technology Studies.

Mugenda, O. \&Mugenda, .A. (2003). Research Methods: Quantitative and Qualitative Research Approaches. Nairobi: Act Press.

Munther, Z. (2013).Using drama activities and techniques to foster teaching English as a foreign language: a theoretical perspective (online) Al Quds Open University (27/12/2013) retrieved from http:/www.qou.edu/English/

Ni'Mah, W. (2015).Introduction: What is reading? In C. Alderson, \& A. H. Urquhart (Eds.), Reading in a foreign language (pp. 16-28). London \& New York: Longman.

Orodho, J. A., Nzabalirwa, Odundo P. A, Waweru \& Ndayambaje (2016).Qualitative and Qualitative Research Methods.Nairobi, Kanezja Publishers \& Enterprises. Kenya

Oros, C., Litcanu, M., Prostean, O., and Mnerie, A. V. (2014).Brain writing Vs. Brainstorming.Case study for Power Engineering Education.Politechnica University of Trimisoara, Romania.

Osborn, A.F., (1953). Applied imagination. Scribner's, New York.

Otieno, N. O. (2003). Relationship between secondary school teachers' attitudes towards integrated English approach and their performance: a study of Rachuonyo district, Kenya. M.Ed thesis, Kenyatta University, Nairobi, Kenya.

Oyibe, J. (2014). Effects of a computer-assisted concept mapping learning strategy on EFLcollege students' English reading comprehension.Computers \& Education, 54, 436-445.

Upandhya, M. F. (2012). Using E-maps to organize and navigate in teaching English as a second language, EDUCAUSE Quarterly, 31 (1), 56-61.

Wambui, H \&Odundo, P (2016) Reforming For Value Creating Education In Primary School Kenya: Addressing Policy And Practice. International Journal of Advanced Research (IJAR) ISSN No: 2320 - 5407: 2017 DOI URL:http://dx.doi.org/10.21474/IJAR01/ 